\title{
DETERMINANTS OF FARMERS' INCOME FROM COMMUNITY FORESTRY IN NAWALPARASI, NEPAL
}

\author{
Badri Khanal ${ }^{1}$
}

\begin{abstract}
Community forest has great impact on forest management but it has put a check on important component of family income of farmerswho directly benefited from the forest. This was due to various factors affectingthe forest income. This study analyzed theforest income determinants in community forestry in Nawalparasi District.Three community forests (Sundaree, Namuna women and Jharahi Plantation) were selected randomly. Ten explanatory variables were examined as determinants of share of gross forest income in gross family income of rural farmers using linear multiple regression analysis assuming all the explanatory variables are significantly related with gross family income. Four variables (economically active female, total land, percent of irrigated land and distance of forest) showed significant relationship with forest income. The paper suggests policy makers for taking proper attention to mainstream forest related programs, which are directly related to rural farmers' income in policy formulation andimplementation.
\end{abstract}

Key words: community forestry, forest income, Nawalparasi, Nepal

\section{INTRODUCTION}

Forests are an integral part of the farming system in Nepal. Farmers must have access to forest products such as leaf materials for fodder and for animal bedding, fuel wood for energy, and timber for buildings and agricultural implements like spade, leveler and plough, raw material for small level forest industry and medicinal and aromatic plants. Agriculture along with forestry contributes 35.3 percent of national GDP. Forest sector contributes 8.12 percent of agricultural GDP in Nepal. Thus, forest sector contributes about 2.7 percent of national GDP (MoF, 2011). Forest products mainly timber wood and non-timber forest products are important source of national revenue.

Following the approval of master plan for the forestry sector (MPFS) in 1989 and the enactment of Forest Act, 1993 and Forest Rules 1995, community forestry (CF) has become the most important program within the Nepal's forestry sector (GoN, 1993; GoN, 1999). As per these policy provisions, local communities are organized as Forest User Groups (FUGs) and entrusted with the responsibilities of management, development and utilization of forest areas that are accessible to the communities. According to the Act, community forestry users groups (CFUGs) have to be established and registered at the District Forest Office (DFO) before handing over of the forests, and they are self sustained institutions (Kanel, 2005). As at mid- march of 2009, there were 14,559 CFUGs established across the

\footnotetext{
${ }^{1}$ Agriculture Economist, Ministry of Agricultural Development, Nepal email: badri.khanal1@gmail.com
} 
country. They managed 1.23 million ha of forests involving 1.66 million households (MoF 2010).

Many studies show the forest income is an important source of family and community income and there are many factors to affect on this. Uprety (2000) based on study carried out in Dolakha and Ramechhap districts of central hills of Nepal concluded that forest based income is a major contribution to the livelihoods of rural people. Community forestry users groups (CFUGs) are operating the forest based micro enterprises. Income generation from forest products like timber, bamboo, medicinal plant, forest nursery, nontimber forest products (NTFPs) had started. Dev et al. (2003) conducted impact study of Community forestry on 11 CFUGs of four eastern hill districts of Nepal(Dhankuta, Terathum, Sankhuwasabha, Bhojpur). They found that impacts were diverse both within and between forest users groups (FUGs), but had been generally positive in terms of improved levels and security of forest product and benefit flows, household income-generating opportunities, support for community infrastructure, development activities, and improved 'social capital' for collective planning and action.

Dhakalet al. (2005) concluded that forage production and availability had decreased with the commencement of CF programs. This paper challenged the assumption that improved forest condition necessarily leads to improvement in livelihoods of the farmers. Kafle (2008) conducted a study on contribution of community forestry on users' household income using data from 92 household of Gorkha district of Nepal. Non-farm sources were found as the major and largest source of income of households contributing 65.5 percent share income followed by agriculture income $(16.9 \%)$, livestock income $(10 \%)$, community forest income (4.2\%) and other forest income (2.3\%). Community forests supported 12.3 percent of total household income to poor, 4.06 percent to middle and only 2.78 percent to rich class households.

Neupane (2008) assessed impact of community forestry on household income in Tribhuwan Municipality of Dang district of Nepal using sample of 100 household. Results indicated that community forest had positive impact on betterment of household economy of the site. The multiple linear regression analysis showed that land holding size and livestock holding size affects the income of the users directly.

These studies show that, the concept of community forestry is not new anymore in Nepal. It has mainly played important role for forest management but the economic status of farmers using those forest has not significantly changed. So, it's necessary to understand all relevant factors and their impact which may play vital role in economic benefit derived from community forestry. Many studies have conducted for these factors, but thosestudies have focused on very limited factors that affect forest income of rural farmers.Keeping these findings in mind, the present study was conducted to assess the ten different factorsthat determine the income of rural farmers from forest and their role on income level. 


\section{METHODOLOGY}

\section{STUDY AREA AND DATA COLLECTION}

The study was conducted in Nawalparasi district in Nepal. The number of community forestry (74), number of member households $(28,413)$ and number of individuals benefited by community forestry $(150,135)$ in Nawalparasi district are among the highest in all the districts inNepal, which compelled to choose Nawalparasi district purposively. There are total 74community forestry users group (CFUGs) that has been handed over by District Forest office(DFO) in Nawalparasi, of which 22 are having experience of more than 5 years. Similarly, there are four women handled community forestry of which only one community forestry had experience of more than 5 years.Among these 22, three CFUGs having experience of more than 5 years of implementation of community forestry program were selected randomly using random number table.Two community forestry from natural forest (Sundaree and Namuna Woman) and one community forestry from plantation forest (Jharahi) were selected randomly in such a way that one woman handled and two co-handled community forestry users groups were included in the study (Table 1).From each community forest users group 30 farmer households were selected randomly using random number table. For the purpose of comparing the performances of individual CFUGs and consistency of information, equal number ofhouseholds were selected, although they had different number of member householdsin the groups (Table 1).

Table 1. Details of selected community forestry users group

\begin{tabular}{llll}
\hline Particulars & Sundaree CFUG & Namuna women CFUG & Jharahi plantation CFUG \\
\hline Address & Amarapuri VDC, ward 1-9 & Devchuli VDC, ward 1,5 \&9 & Rajahar VDC ward no. 6\& 8 \\
Handover year & 1998 & 1996 & 1996 \\
Area & 364.75 ha & 103.00 ha & 30.80 ha \\
Type of forest & Natural forest & Natural forest & Plantation forest \\
Number of member HH & 1032 & 189 & 240 \\
\hline
\end{tabular}

Source: Field Survey, 2010

\section{ANALYTICAL FRAMEWORK}

To find out the determinants of forest income, ten explanatory variables were selected based on communication with community and study from different literatures to examine their affect on income from the forest. The pre screening of the selected explanatory variables was conducted through Multicollinearity, autocorrelation and normality tests.

For multicollinearity test two methods were used. Pearson correlation coefficient was calculated for screening of independent (explanatory variables) by examining degree association between different pairs of explanatory variables and between explanatory variables and dependent variables through zero order correlation matrixes. This is because, higher degree of association among explanatory variables suggest for multicollinearity. The sample correlation coefficient is 


$$
r_{x y}=\frac{\sum_{i=1}^{n}\left(x_{i}-x\right)\left(y_{i}-\bar{y}\right)}{(n-1) s_{x} s_{y}}
$$

where $\bar{x}$ and $\bar{y}$ are the sample means of $\mathrm{X}$ and $\mathrm{Y}, s_{x}$ and $s_{y}$ are the sample standard deviation of $X$ and $Y$. The cut-off value for existence of multicollinearity was taken as correlation between any pair of variables above than 0.70 (Guajarati, 2004).

Similarly, Variance Inflation Factor (VIF) and Tolerance Factor (TOL) were also used in identifying multicollinearity. For a typical regression coefficient (Say)

$$
\begin{aligned}
& \operatorname{VIF}\left(\hat{\beta}_{1}\right)=\frac{1}{1-R_{1}^{2}} \ldots \ldots \ldots \ldots \ldots \ldots \ldots \ldots \ldots \ldots \\
& \operatorname{TOL}\left(\beta_{1}^{\infty} 1\right)=\frac{1}{\operatorname{VIF}\left(\hat{\beta}_{1}\right)}=1-R_{1}^{2}
\end{aligned}
$$

where, $R_{1}{ }^{2}$ is the value of multiple determinations obtained after running auxiliary regression, that is regression of variable on the remaining $X$ variables. Similarly, VIF and TOL can be calculated for all other $\mathrm{X}$ variables.

Durbin Watson ' $d$ ' test was done to see the correlation among successive value of same variable. In numerator of the ' $d$ ' statistic the number of observation is $n-1$ because one observation is lost in taking successive differences (Guajarati, 2004).

$$
d=\frac{\Sigma_{\mathrm{t}=2}^{\mathrm{n}}\left(\hat{\mathrm{\mu}}_{\mathrm{t}-}-\hat{\mathrm{\mu}}_{\mathrm{t}-1}\right)^{2}}{\Sigma_{\mathrm{t}=1}^{\mathrm{n}} \hat{\mu}_{\mathrm{t}}^{2}}
$$

The value of 'd'statistic varies from 0 to 4 ; based on its value the presence or absence of autocorrelation was concluded. Then a visual test with Q- Q plot2 was used to test the normality of the data.

Multivariate regression model was used to estimate relationship between forest incomeand selected explanatory variables. Based on the result of $\mathrm{Q}-\mathrm{Q}$ plot, the linear function was assumed for the present study:

$Y=a+B_{1} X_{1}+B_{2} X_{2}+B_{3} X_{3}+B_{4} X_{4}+B_{5} X_{5}+B_{6} X_{6}+B_{7} X_{7}+B_{8} X_{8}+B_{9} X_{9}+B_{10} X_{10}+\mu$

where, $Y=$ Percent of gross forest income in gross family income.

$X_{1}=$ Number of economically active male members of family

$X_{2}=$ Number of economically active female members of family

$\mathrm{X}_{3}=$ Ethnicity of the respondent (dummy, low caste $=1$, upper caste $=0$ )

$X_{4}=$ Number of school years of family head

$X_{5}=$ Total land in hectare.

$\mathrm{X}_{6}=$ Percentage of irrigated land in total land area. 
$X_{7}=$ Number of livestock in standard livestock unit.

$\mathrm{X}_{8}=$ Distance of forest from house in $\mathrm{Km}$.

$\mathrm{X}_{9}=$ Number of trees grown in private land.

$X_{10}=$ Number of trainings taken from community forestry.

$\mu=$ Disturbance or error term

$a=$ constant value and $B_{1}$ to $B_{10}$ are regression coefficients of the respective variables, whose significance is tested.

For easiness in computation, the dependent variable was used as percentage. The forest income was calculated adding all the forest related income like fuel wood, bedding materials, and herbal products etc., and assuming price at local market. The overall significance of multiple regressions was tested using f-test with ANOVAapproach. The test consists of null hypothesis $\left(\mathrm{H}_{0}\right)$ that all regression coefficients aresimultaneously not statistically different from value zero versus alternate hypothesis $\left(\mathrm{H}_{1}\right)$ that allthe regression coefficients ( $B$ 's) are statistically different from value zero simultaneously. Thetest statistic was calculated as:

$$
\text { Fcal }=\frac{M S S_{E}}{M S S_{R}}=\frac{\frac{\mathrm{ESS}}{\mathbf{k}}-\mathbf{1}}{\frac{R S S}{n}-k}
$$

Where, ESS = regression sum of square; RSS= residual sum of square; $k-1$ is degree of freedomfor regression and $n-k$ is degree of freedom for residuals where $n$ is number of observations andk is numbers of explanatory variables.

\section{RESULTS AND DISCUSSIONS}

\section{RESULTS OF PRELIMINARY SCREENING}

The mean values of variables and zero order correlation results are presented in Table 2and Table 3, respectively. The result shows that the average gross forest income after communityforestry was 5.85 percent as per sample estimate. The highest deviation from its mean was foundin case of percentage of the irrigated land on total land area.

The result of multicollinearity test among explanatory variables shows that there does not exist multicollinearity. First, the simple correlation among all explanatory variables were observed (Table 3), the cut-off value for multicollinearity was taken at 0.7 (Guajarati, 2004). No pairs of explanatory variables showed the presence of multicollinearity.

In addition to this, varianceinflation factor (VIF) and tolerance factor (TOL) were also calculated (Table 4). Cut off value oftolerance factor for presence of multicollinearity was taken below 0.1 for all explanatoryvariables, no value was found below than 0.1 . Cut-off value for VIF value of explanatoryvariable was taken 
as 10. For all explanatory variables, the value of VIF was below cut-offvalue. Thus there was no multicollinearity among explanatory variables.

Table 2. Descriptive statistics

\begin{tabular}{|c|c|c|c|c|}
\hline Variables & Mean & Minimum & Maximum & $\begin{array}{l}\text { Std. } \\
\text { Deviation }\end{array}$ \\
\hline Percent of gross forest income in gross family income $(\mathrm{Y})$ & 5.85 & 0.13 & 29.02 & 6.67 \\
\hline Number of economically active male members of family $\left(X_{\mathbf{1}}\right)$ & 1.92 & 1.00 & 5.00 & .91 \\
\hline Number of economically active female members of family $\left(X_{z}\right)$ & 1.99 & 1.00 & 5.00 & .89 \\
\hline Ethnicity of respondent $\left(X_{\mathrm{g}}\right)($ Bhramin\&tkshetri $=0$,others $=1)$ & .54 & 0.00 & 1.00 & .50 \\
\hline Number of school years of family head $\left(X_{4}\right)$ & 5.42 & 0.00 & 15.00 & 3.92 \\
\hline Total land in hectare $\left(X_{5}\right)$ & .74 & 0.01 & 3.16 & .61 \\
\hline Percentage of irrigated land in total land area $\left(X_{6}\right)$ & 58.51 & 0.00 & 87.24 & 22.56 \\
\hline Number of livestock ( $\tilde{X}_{\bar{J}}$ ) ( in standard livestock unit) & 2.19 & 0.00 & 6.40 & 1.38 \\
\hline Distance of forest from house in $\mathrm{km}\left(X_{\mathrm{a}}\right)$ & .81 & 0.10 & 1.90 & .47 \\
\hline Number of trees grown in private land $\left(\tilde{X}_{\mathbf{g}}\right)$ & 3.11 & 0.00 & 19.00 & 4.16 \\
\hline Number of trainings taken from $\mathrm{CF}\left(X_{10}\right)$ & 1.03 & 0.00 & 7.00 & 1.23 \\
\hline
\end{tabular}

Table 3. Zero order correlation matrix (Pearson's correlation)

\begin{tabular}{|c|c|c|c|c|c|c|c|c|c|c|c|}
\hline Variables & Y & $X_{1}$ & $x_{2}$ & $x_{3}$ & $X_{4}$ & $X_{5}$ & $x_{6}$ & $x_{7}$ & $X_{8}$ & $X_{9}$ & $x_{10}$ \\
\hline Y & 1 & -.15 & .42 & .19 & -.47 & -.56 & -.64 & .01 & -.49 & -.54 & -.31 \\
\hline$X_{1}$ & & 1 & .25 & .04 & -.02 & .23 & .08 & .14 & .11 & .19 & .11 \\
\hline$x_{2}$ & & & 1 & .19 & -.34 & -.16 & -.15 & .16 & -.31 & -.28 & -.06 \\
\hline$x_{3}$ & & & & 1 & -.14 & -.17 & -.02 & -.02 & -.27 & -.24 & -.27 \\
\hline$X_{4}$ & & & & & 1 & .31 & .36 & .07 & .22 & .29 & .03 \\
\hline$X_{5}$ & & & & & & 1 & .39 & -.05 & .28 & .56 & .28 \\
\hline$x_{6}$ & & & & & & & 1 & .05 & .18 & .23 & .11 \\
\hline$X_{7}$ & & & & & & & & 1 & -.21 & -.26 & -.09 \\
\hline$x_{8}$ & & & & & & & & & 1 & .59 & .38 \\
\hline$X_{9}$ & & & & & & & & & & 1 & .41 \\
\hline$X_{10}$ & & & & & & & & & & & 1 \\
\hline
\end{tabular}

Note: $\mathrm{Y}=$ dependent variable, $\mathrm{X}_{1}-\mathrm{X}_{10}=$ explanatory variables 
The Durbin-Watson test showed that the value of $d$ statistics $(d=1.994)$ emerged with in the region of no autocorrelation (Table 4). Thus, autocorrelation did not exist in the data. After screening of selected socio-economic variables through correlation analysis, normality test wasconducted to observe the normal distribution of variables. The Q-Q plot for normality test showed that all the variables were distributed normally, as plotted points approximately lie on straight line (Figure 1).So, multiple regression analysis wasdone in linear

Normal Q-Q Plot of Number of economically active male members of family

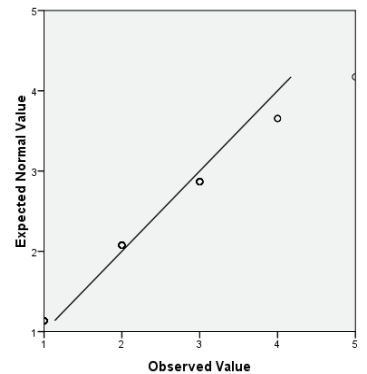

Normal Q-Q Plot of Total land in hectare

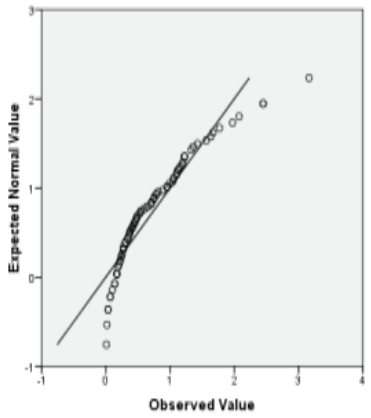

Normal Q.Q Plot of Percent of gross forest income in gross family income

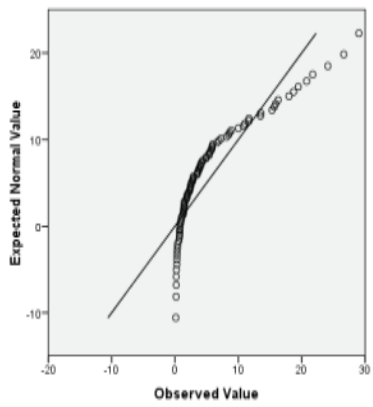

Normal Q-Q Plot of Number of economically active female members of family

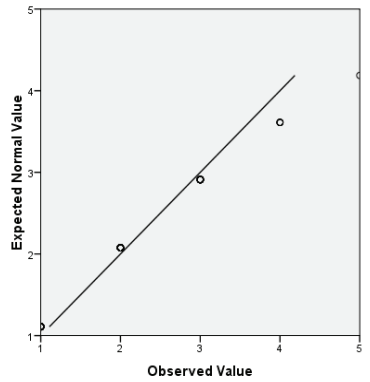

Normal Q-Q Plot of Number of school years of family head

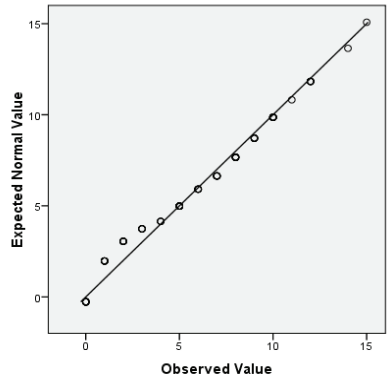

Normal Q-Q Plot of Percentage of irrigated land in total land area

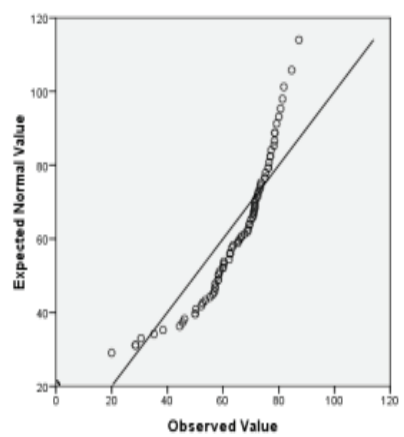


Normal Q-Q Plot of Number of livestock in standard livestock unit

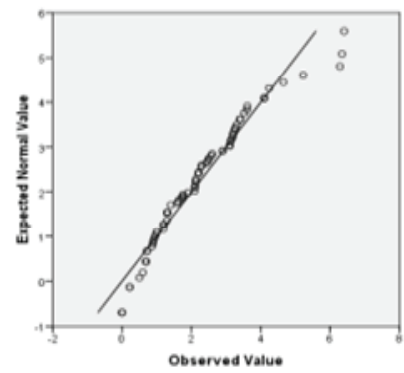

Normal Q.Q Plot of Distance of forest from house

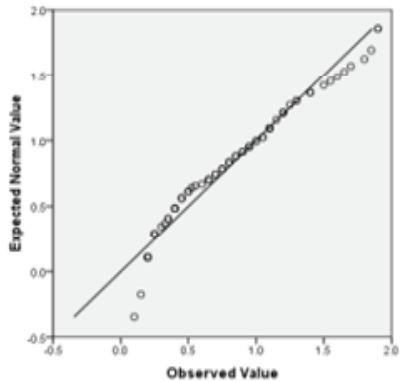

Normal Q.Q Plot of Number of trees grown in private land

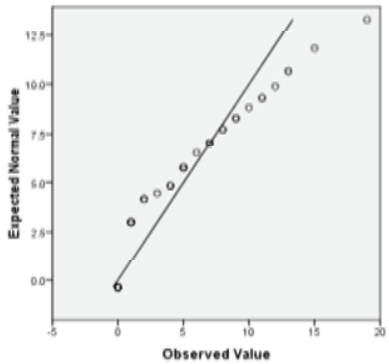

Normal Q-Q Plot of Number of trainings taken from community forestry

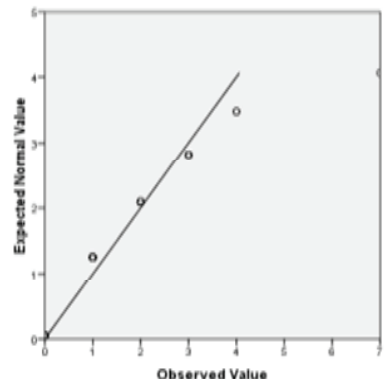

Figure 1. Normal Q-Q plots of dependent and explanatory variables

\section{RESULTS OF REGRESSION ANALYSIS}

The regression results are presented in Table 4 . The results indicated that theeconomically active male members $\left(X_{1}\right)$ of the family have a non significant relation with theshare of forest in gross family income $(Y)$. This may be because most of the economically active male are involved in other works rather than forest related works. The number of economically active femalemembers of family $\left(X_{2}\right)$ exercised a significant positive impact on share of forest income (withcoefficient 1.664). Which suggest us, female do have direct employment from forest in most of the cases. Usually female go to forest for firewood, animal bedding and other purposes.

The ethnicity of the respondent $\left(X_{3}\right)$ was found to have non-significant influence on shareof forest income in gross family income. All the people, regardless of their ethnicity had equally using forest for their livelihood, as a result of which, the hypothesis that there might be different effect for different ethnic people is not true. Similarly, the number of school years of the familyhead $\left(X_{4}\right)$ did not appear to be a significant determinant of share of forest income in gross familyincome.The people regardless of their education level are equally benefited from the forest. 
Table 4. Results of regression analysis

\begin{tabular}{|c|c|c|c|c|c|c|c|c|}
\hline & \multicolumn{4}{|c|}{$\begin{array}{l}\text { Unstandardized } \\
\text { Coefficients }\end{array}$} & \multicolumn{2}{|c|}{$\begin{array}{l}\text { Collinearity } \\
\text { Statistics }\end{array}$} & \multirow[t]{2}{*}{$\begin{array}{l}\text { Durbin Watson } \\
\text { d statistic }\end{array}$} & \multirow{2}{*}{$\begin{array}{l}\text { The land holding } \\
\text { of family }\left(\mathrm{X}_{5}\right)\end{array}$} \\
\hline & B (beta) & Std. Error & $\mathrm{t}$ & sig & TOL & VIF & & \\
\hline Constant & 17.050 & 2.070 & $8.237^{*}$ & 0.000 & & & & \\
\hline $\mathrm{X} 1$ & -0.555 & 0.507 & -1.094 & 0.277 & 0.803 & 1.245 & & negative \\
\hline$X 2$ & 1.664 & 0.545 & $3.050^{*}$ & 0.003 & 0.728 & 1.373 & & coefficient \\
\hline X3 & 0.077 & 0.900 & 0.085 & 0.932 & 0.851 & 1.176 & & 1.882)impact \\
\hline $\mathrm{X} 4$ & -0.187 & 0.124 & -1.510 & 0.135 & 0.728 & 1.373 & & share of incom \\
\hline X5 & -1.882 & 0.902 & $-2.086^{* *}$ & 0.040 & 0.575 & 1.738 & & from forest. $\mathrm{Tr}$ \\
\hline X6 & -0.125 & 0.021 & $-5.943^{*}$ & 0.000 & 0.768 & 1.302 & & means, th \\
\hline $\mathrm{X} 7$ & -0.312 & 0.329 & -0.946 & 0.347 & 0.838 & 1.194 & 1.994 & having high \\
\hline $\mathrm{X} 8$ & -2.614 & 1.162 & $-2.250^{* *}$ & 0.027 & 0.584 & 1.713 & & land holding $\mathrm{h}$ \\
\hline X9 & -0.178 & 0.153 & -1.159 & 0.250 & 0.426 & 2.347 & & is income $\mathrm{fi}$ \\
\hline $\mathrm{X} 10$ & -0.409 & 0.390 & -1.050 & 0.297 & 0.751 & 1.331 & & T \\
\hline
\end{tabular}

higher land holding might be more busy on agricultural practices than going to forest for different forest products. The share of irrigated land in total land area $\left(X_{6}\right)$ of theusers was found to have a significant negative impact on forest income of users. This was because, irrigated land holding people could have better production from their land and income from land. So, they need not to depend more on forest. The regressionresults show that the number of livestock $\left(X_{7}\right)$ is a non-significant determinant of share of forestincome in gross forest income. There were mainly two reason for that. First, animals are not allowed to enter into forest area and secondly, size of animal holding was itself not so big in the area.

The distance of house from forest $\left(X_{8}\right)$ was found to havesignificant negative relation (coefficient $=-2.614$ ) with share of forest income. This gives an idea that people nearby forest had more access to forest, easy to reach their and were more benefited. The number of trees grown in private land $\left(X_{9}\right)$ did not appear to be significantdeterminant of share of forest income in gross family income. This was because the number of trees in private forest were not significantly high resulting no specific effect on forest income of people. The number of trainings taken from CF $\left(\mathrm{X}_{10}\right)$ by the users was also found to have a non-significant impact on share offorest income in gross family income of the users. That's why; the training was either not sufficient in number of participants or number of events or was less value for forest users. Also, the people could have not utilized their knowledge gained during training.

The result of ANOVA (i.e. f-test) indicated that the overall regression model wassignificant at $95 \%$ confidence interval (Table 5). The model indicated that as much as 69.3percent of variation in share of forest income in gross family income of users was togetherexplained by ten variables of which four variables appeared as significant determinants. 
Table 5. ANOVA and model for overall significance of regression model

\begin{tabular}{llllll} 
ANOVA & \multicolumn{1}{l}{ Mean Square } & $\mathrm{F}$ & Sig. \\
\hline Particulars & Sum of Squares & Df & M & .000 \\
\hline Regression & 2747.102 & 10 & 274.710 & $17.865^{*}$ & \\
Residual & 1214.789 & 79 & 15.377 & & \\
Total & 3961.892 & 89 & & & \\
\hline
\end{tabular}

MODEL

\begin{tabular}{llll}
\hline $\mathrm{R}$ & R Square & Adjusted R Square & $\begin{array}{l}\text { Std. Error of the } \\
\text { Estimate }\end{array}$ \\
\hline .833 & .693 & .655 & 3.92136 \\
\hline
\end{tabular}

Note: Dependent Variable: percent of gross forest income in gross household income. ${ }^{*}=$ significant at 1 percent level, ${ }^{* *}=$ significant at 5 percent level

\section{CONCLUSIONS}

The income from forest is being one of the important sources of family income in ruralhouseholds of Nepal. The study of different factors related with forest income, suggests us manypolicy issues for the betterment of the people dependent on forest for their livelihood.First of all, users having higher number of active female membersshould be provided higher attention than male members during formation of policy targeting individual family. Particularly, involving women in every process of the community forest is an idea. Involving women in other income generating activities from forest like forest product production, agro-forestry would be helpful. Thus, family having higher numberof economically active female members of household may be helpful in generating higher shareof income from the community forest.

The inclusion of the users havinglow land holding may be helpful in generating higher percentage of income from the forest. The negative coefficient of share ofirrigated land in total land area suggests that those having small share of irrigated land will havegreater interest and motivation in participation in community forestry. They should beincluded and kept in view while forming forest use policy and implementation practices.

Significant negative relation of the distance of house from forest suggests that thoseliving near to forest are getting more income from forest than distant dwellers. Thus, dwellersnearer to forest will be more interested in CF programme. The number of trainings under taken from community forestry by the users was alsofound to have a non-significant impact on share of forest income in gross family income of theusers. This suggests that more effective, more frequently and useful training programme design and deliveryand follow up after training needs tobe considered.Thus, the present study suggest that many factors having highly significantrelationship should be selected and provided higher attention during the process of policyformulation and implementation practices. 


\section{ACKNOWLEDGEMENT}

The author is very thankful to Emeritus Professor S.K. Teewari of G.B.Pant University of Agriculture and Technology, Uttarakhand, India for overall guidance in collection and analysis of data.

\section{REFERENCES}

Dev,O.P., N.P.Yadav, O.S. Baginski, and J.Soussan, 2003. Impacts of CommunityForestry on Livelihoods in the Middle Hills of Nepal. Journal of Forest and Livelihood 3(1)July, 2003.

DFO. 2009. Nawalparasi district and activities of forest development (in Nepali). Hamrobanmala. Year 6. No 6 pp: 1-14.

Dhakal, B., H.Bigsby and R. Cullen, 2005. Impacts of Community Forestry Developmenton Livestock-Based Livelihood in Nepal. Journal of Forest and Livelihood 4(2) February,2005.pp: 43-49.

Guajarati, N. D., 2004. Basic Econometrics. 4th ed. New York, Tata McGraw-HillPublishing Company Limited. 1002p.

GoN, 1993. Forest Act 1993. Department of Forest, Ministry of Forest and SoilConservation, Government of Nepal. Kathmandu, Nepal.

GoN, 1999. Guideline for Inventory of Community Forests. Community and Private ForestDivision, Department of Forest, Ministry of Forest and Soil Conservation, Government of Nepal. Kathmandu, Nepal.

Kafle, M.R., 2008. Contribution of community forestry to users' household income: Afinancial analysis. Thesis, M.sc. forestry, Institute of Forestry, Tribhuvan University, Nepal.111p.

Kanel, K.R., 2005. Nepal - Community Forestry 2005. Community Forestry Policy Forum, RECOFTC, Bangkok, Thailand, August 2005. 50p

MOF, 2010. Economic survey of fiscal year 2008/09. Ministry of Finance, Government ofNepal, Kathmandu, Nepal.

MOF, 2011. Economic Survey of fiscal year 2009/10. Ministry of Finance, Government ofNepal. Kathmandu, Nepal.

Neupane, H., 2008. Impact of community forestry in household economy of dang district inNepal. Thesis, M.Sc. Ag., Institute of Agriculture and Animal Sciences, TribhuvanUniversity, Nepal. 89p.

Upreti, B.R., 2000. Social transformation through community forestry: Experience andlessons from Nepal. Mountain forum online library document. 